\title{
Visionários
}

\section{A imaginação republicana}

\section{nas Minas setecentistas}

"Eu tenho um coração maior que o mundo" (Tomás Antônio Gonzaga).

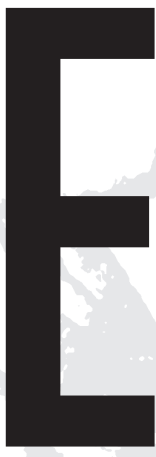

m um poema datado de 1773, Vila Rica

( I), Cláudio Manuel da Costa retomou, de maneira exemplar na literatura brasileira, um tema particularmente importante no processo de constituição das matrizes da tradição republicana, presente tanto em sua versão clássica quanto a partir de suas versões renascentista e moderna: o tema da fundação. Com efeito, ao desenhar o argumento de seu poema, Cláudio Manuel da Costa insinuou, no interior de uma estrutura MURGEL STARLING 


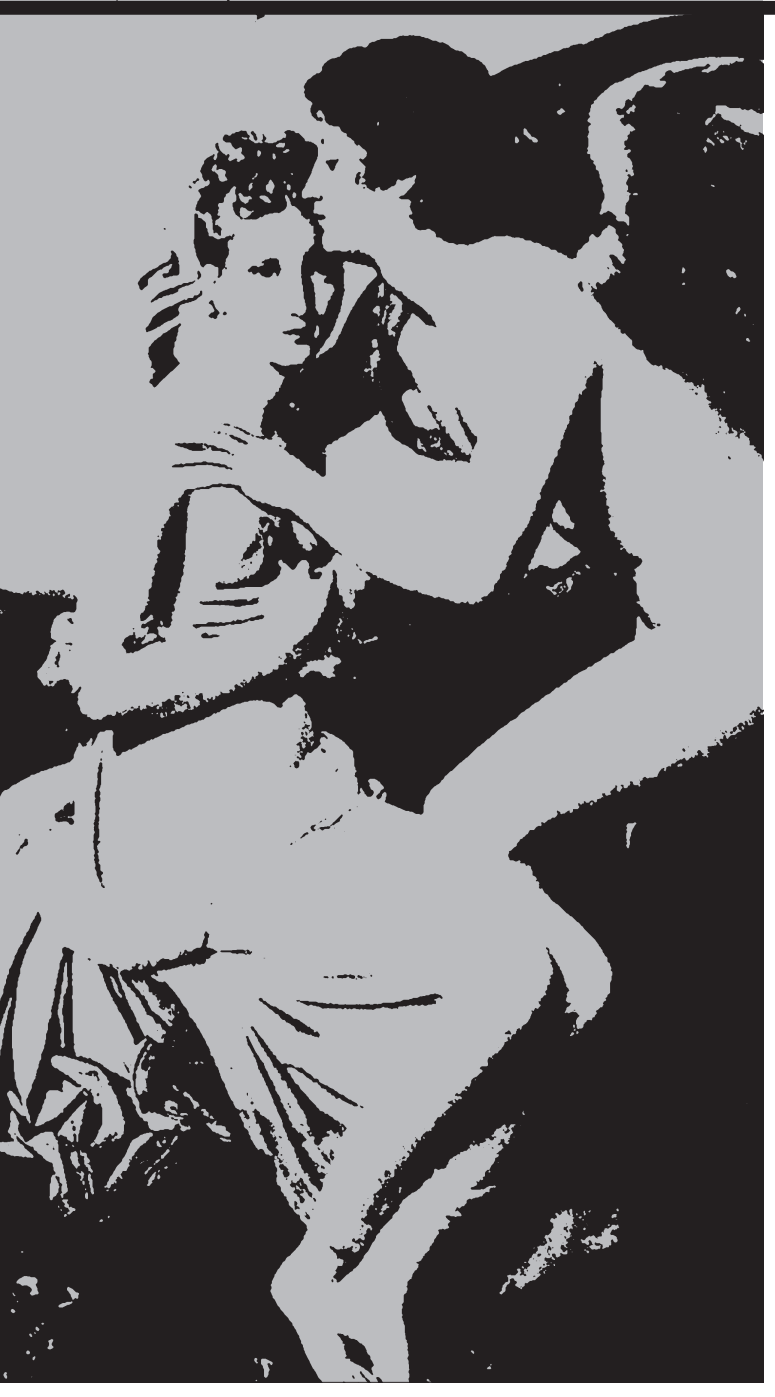

bilidade da existência de um ponto de articulação entre a oportunidade da criação de formas de vida em comum e a cena de construção de cidades, uma cena sempre estratégica para consideração do tema da fundação (2).

Assim, a Vila Rica cantada por Cláudio Manuel da Costa surge suavemente embalada por uma ética da vida ativa, uma ética que serve, ao mesmo tempo, ao engajamento do indivíduo no mundo comum da cidade e à cons- trução de uma narrativa sobre os fatos memoráveis do passado. Construída em versos decassílabos, distribuída em dez cantos e composta já no tempo da maturidade e da velhice de um poeta cuja produção vinha sendo até então dominada pelo sentimento nostálgico de perceber-se estrangeiro na própria terra, Vila Rica tem por objetivo apresentar o momento, na história, em que ocorreu a criação de algo novo - a descoberta do ouro na região das Minas, a novidade da fundação de uma cidade capaz de alterar o cenário no qual surgiu, já que ao menos poeticamente irá se encontrar inscrita nele como entidade autônoma.

Essa era, sem dúvida, uma novidade importante para a composição da imaginação republicana das Minas da segunda metade do século XVIII. Na verdade, o poema de Cláudio Manuel da Costa procurou ansiosamente realizar um exercício de rememoração da origem sobretudo por duas razões: em primeiro lugar, porque esse exercício costuma sempre trazer dobrado em seu interior a percepção de um certo senso de história, em geral associado à decifração do sentido da obra a ser realizada pelo conjunto dos homens que povoam a cidade. Em segundo lugar,
Cláudio Manuel da Costa "Vila Rica", in Domício Proenca Filho (org.), A Poesia dos Inconfidentes; Poesia Comple ta de Cláudio Manuel da Costa Tomás Antônio Gonzaga e Alvarenga Peixoto, Rio de Ja neiro, Nova Aguilar, 1996.

2 A esse respeito ver especial mente: Newton Bignotto, Três Maneiras de se Criar uma Cidade, Belo Horizonte, 200 (mimeo.): Quentin Skinner, A Fundações do Pensamento Po lítico Moderno, São Paulo, Companhia das Letras, 1999 
porque também deriva do recurso ao passado e da localização de suas formas inaugurais a compreensão sobre a maneira como a identidade de uma dada cidade veio a ser produzida.

No caso de Vila Rica o poema tratou de afirmar essa identidade recorrendo, como no modelo grego clássico, aos particulares vínculos da cidade com aquilo que estava fora do tempo (3). Com uma diferença, porém. Rastreada pelo olhar europeu como uma terra demasiadamente juvenil, sem lastro de antigüidade e, portanto, incapaz de possuir tradição venerável ou passado remoto, nas condições históricas da região das Minas, entre os séculos XVII e XVIII, o recurso à mitologia, pela fantasia literária do Setecentos, converteu-se em genuína necessidade poética, ou, se quisermos, em evidente expediente compensatório.

Contudo, diferentemente do que aconteceu, por exemplo, no entrecho poético do Caramuru, de Santa Rita Durão, ou do Uraguai, de Basílio da Gama, Vila Rica é um poema sobre a fundação de uma cidade nas condições particulares da ação autônoma dos homens. Além disso, nesse poema, a evocação do vínculo que a cidade estabeleceu com a narrativa mitológica das origens ganha, talvez, novo acento, já que heróis e deuses são configurados e redimensionados, pela linguagem, de maneira curiosamente híbrida, resultado de uma mistura bem dosada entre o uso de formas e imagens caras ao discurso árcade europeu e os efeitos de imaginação produzidos por um novo mundo que o elemento nativo concebeu e semeou.

Região desconcertada pelo estranhamento e reencontrada pela imaginação do poeta no momento inaugural de sua trajetória, nas Minas, cantadas por Cláudio Manuel da Costa, o acervo milenar do imaginário mitológico europeu acoplou-se ao universo local e foi, simultaneamente, fecundado por ele. Como resultado, os bandeirantes que um dia partiram das vilas paulistas em suas lides sertaneja e predadora tornaram-se os filhos de Marte alçados à dimensão épica do herói, o Ribeirão do Carmo, em múltiplas e expressivas tentativas de metamorfose, se fez vizinho ao Tejo para dominar de amorosa inveja a vida das divindades européias e as ninfas dos córregos de água turva e feia polvilharam seus cabelos com o ouro em pó extraído dos rios, em parte para torná-los louros, em parte para reproduzir o gesto soberbo das damas que habitavam as vilas mineiras, damas lendárias que empoavam de branco os próprios cabelos e cobriam de ouro puro a carapinha das negras de estimação (4).

Mas Vila Rica, em sua busca desesperada de origens, também não deixou dúvidas quanto à decisão do poeta de orientar sua estratégia pela utilização de um forte senso de história, prática pouco usual em textos de poesia à época. Com efeito, por algum motivo, Cláudio Manuel da Costa dedicou grande atenção à interpretação e à escrita de uma história capaz de sublinhar a natureza singular do chão urbano de Vila Rica e recheou seu poema com um extenso conjunto de notas e com a introdução de um "Fundamento Histórico" que o precede e funciona como uma espécie de memória da capitania das Minas.

Na prática, o "Fundamento Histórico" acabou compondo, de fato, uma memória de conteúdo bastante vasto, orientada por um esforço de descrição das possibilidades naturais, econômicas e, principalmente, das possibilidades de intervenção da ação humana no território mineiro. A opção pelo gênero literário memória sugerindo a intenção do poeta de processar uma ampla avaliação dessas condições, inclusive, talvez, para compreender o estado de decadência em que se encontrava a capitania das Minas ao final do século XVIII, aponta, no caso específico da composição de Vila Rica, para a adoção de uma estratégia preocupada em fundamentar o discurso poético sobre as origens da cidade e seus posteriores desdobramentos na solidez documental de um aparato crítico de referências, citações e indicações de fontes de caráter histórico, geográfico e cultural (5).

Também por essa razão há quem considere Cláudio Manuel da Costa, entre os autores mineiros do Setecentos, "o mais profundamente preso às emoções e valores da 
terra" (6). Entretanto, quaisquer que tenham sido suas motivações, inclusive as de fundo nativista, vale observar que a construção dessa espécie de memória histórica da capitania e de suas origens, precedendo os versos de Vila Rica, sempre indicou a preocupação do poeta em apontar a ação voluntária dos homens como fator fundamental para considerar a construção da identidade de uma comunidade. Mais do que isso, talvez, na sugestão do poema, a virtuosidade da ação desses homens, isto é, a excelência com que responderam às oportunidades que a fortuna - ou, nos termos do poema, que o gênio Itamonte, transfor- mado em penhasco, pela fúria dos deuses - abriu ante eles, tornou-se condição para entender todo o desenvolvimento posterior da vida da cidade.

Essa foi uma outra novidade decisiva para compor a imaginação republicana mineira do século XVIII. Provavelmente por conta dela, Vila Rica passou a carregar, no seu centro, a marca de um artifício: o território das Minas pertencia ao vasto império português, era uma das mais importantes, populosas, ricas e estrategicamente bem posicionadas capitanias brasileiras ainda no final do Setecentos e não parecia haver como escapar dessa realidade no momento em que

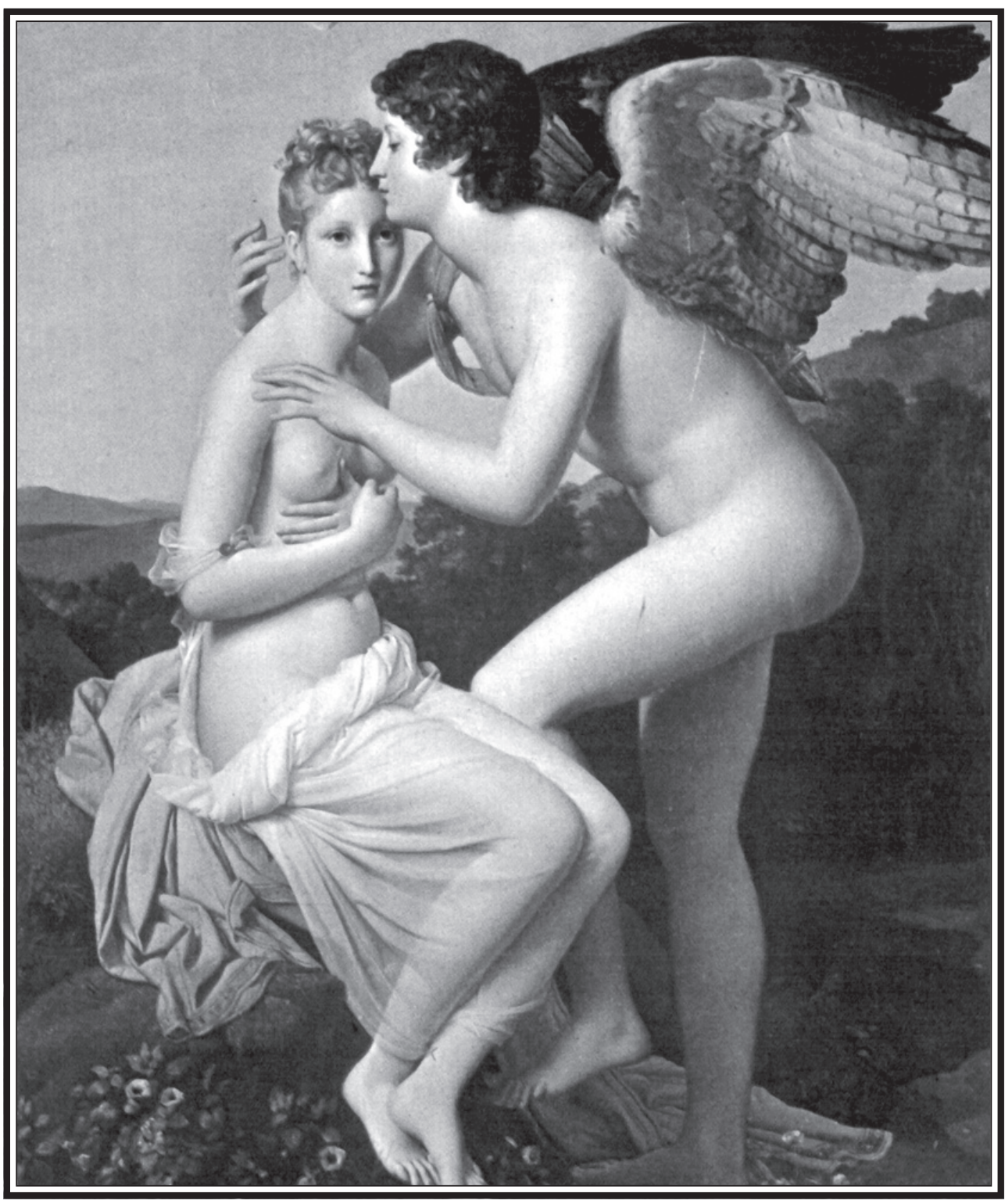

6 Antonio Candido, Formação da literatura Brasileira. Momentos Decisivos 11750 1836), São Paulo/Belo Horizonte, Martins/Itatiaia, 1990 v. 2, p. 88

Psiquê Recebe

o Primeiro

Beijo do Amor, de François

Gérard 
Cláudio Manuel compunha seus versos.

A não ser, talvez, raciocinando poeticamente sobre o terreno fluido e difuso das origens, projeto que permitiu, inclusive, ao poeta, inserir no texto do poema a novidade de uma variável política sustentada no esforço e na autonomia do agente humano em sua tarefa de criar uma nova forma de vida em comum - variável curiosamente característica da matriz republicana que emergiu nas cidades do norte da Itália, em especial, Florença, ao final do século XIV e começo do século XV (7). De fato, raciocinar sobre as origens, no caso do poema Vila Rica, significou também reencontrar o impulso original e fundador da cidade dentro do território da capitania das Minas, e esse reencontro, por sua vez, permitia entender os acontecimentos da história do ponto de vista da ação dos homens que realizaram o ato de sua fundação.

Evidentemente, é muito arriscado especular até onde iriam os conhecimentos de Cláudio Manuel da Costa sobre o surgimento de uma forma nova de organização social e política que, ao final do período medieval, converteu as cidades do norte italiano em repúblicas independentes. Também é arriscado prever se o poeta mineiro reconhecia a evidência, muito mais subversiva, apontada pela vida política dessas cidades, de que a monarquia hereditária, ao contrário da convicção que então prevalecia no mundo europeu, não era a única forma possível para a realização do bom governo.

Contudo, é possível afirmar, com razoável dose de certeza, que Cláudio Manuel da Costa não foi apenas um estudante em cânones, na Universidade de Coimbra, habilitado, portanto, a interpretar velhos autores latinos na sua língua original. Muito mais do que isso, ele foi principalmente um poeta que a literatura do século XVIII reconduziu, primeiro, aos autores trecentistas e quatrocentistas italianos, em particular de Petrarca a Sannazaro, autores que, por sua vez, remontam ao passado grecolatino. Só depois esse processo completouse misturando suas fontes intelectuais à influência das correntes do próprio século e aos portugueses do século XVI, não por acaso, também eles, em grande parte, tributários da raiz renascentista (8).

No caso da poesia de Cláudio Manuel, a face mais visível da presença dessa raiz pode ser percebida, por exemplo, nos procedimentos de apropriação de traços do lirismo renascentista, em geral passíveis de referência na tradição petrarquista. Petrarca era, sem dúvida, uma fonte inesgotável de inspiração formal ou estilística para os poetas dos séculos seguintes, inclusive em função dos procedimentos literários que consolidou ou inventou e que estariam na origem da revolução que iria acontecer na segunda metade do Quatrocentos prolongando-se até meados do século seguinte.

Mas Petrarca foi também provavelmente um dos primeiros florentinos a associar textos de cultura greco-latina clássica com uma nova visão da vida política e dificilmente teria escapado à formação intelectual de um autor que tem antecedentes na raiz petrarquista, o lugar conturbado preenchido por sua obra na promoção da passagem de uma concepção da vida humana na qual a contemplação ocupa um lugar central para uma concepção da vida centrada na cidade e nos valores do mundo público. Tampouco passaria desapercebida a esse mesmo autor a profunda modificação introduzida por Petrarca no interior do antigo culto medieval ao tema da pátria, associando seu significado, não mais à linguagem da Igreja e da Patrística que tornavam o homem cidadão de uma cidade transcendente, a cidade celestial de Jerusalém, a comunidade dos abençoados e santos, mas ao fato de que os homens vivem na terra e habitam o mundo e essa condição tem sempre alguma relação com a política, com a vida em comum, com a vida na cidade - por conta disso, essa cidade, essa pólis, é sempre obra da ação e do gênio humano (9).

Entretanto, a maneira como a poesia de Cláudio Manuel valorizou essa parcela de sua herança intelectual não deixou de ser reveladora das condições peculiares de inserção política de um vassalo letrado, nascido na América Portuguesa, capaz de ver a si mesmo como português $e$ americano, 
mergulhado no contexto histórico de decadência das Minas durante a segunda metade do século XVIII (10). Não por acaso, no argumento do poema, descobrir a origem de Vila Rica significava sobretudo valorizar a ação de um grupo muito específico de homens, os paulistas, uma gente que parecia haver nascido no planalto de Piratininga quase que somente para perambular pelo sertão e deslocar-se livremente sobre espaços cada vez maiores, como se fosse vocacionada para esses espaços ou movida por uma espécie de paixão ambulatória:

"Cante do Lusitano a voz sonora Os claros feitos do seu grande Gama Dos meus paulistas honrarei a fama" (11)

Nesse cenário, porém, o herói do poema, tanto quanto seus principais comparsas, carregava consigo uma ambivalência estrutural. Antonio de Albuquerque, o fundador de Vila Rica, foi, de fato, uma personalidade destacada do império português, um governador escolhido a dedo para assumir a capitania de São Paulo e Minas do Ouro em meio ao conflito emboaba e um fundador de cidades: criou as vilas de Ribeirão do Carmo, Vila Rica e Vila Real de Nossa Senhora da Conceição (12). Mas, embora fidelíssimo ao seu soberano, Antonio de Albuquerque era também filho de um importante funcionário colonial nascido na América Portuguesa. Se não era paulista, insinuava o Vila Rica, acima de tudo era justo, era capaz de abraçar essa causa contra a perfídia dos portugueses emboabas e isso o tornava parte dessa gente que possuía um passado livre e uma vocação para a grandeza.

Também faziam parte dessa mesma gente e sofriam da mesma ambivalência seus companheiros notáveis, aqueles personagens que, nos termos do poema, foram procurados por ele e o ajudaram a levar a cabo as palavras e o feito começado: Garcia Rodrigues Pais e Manuel da Borba Gato. O primeiro, o primogênito do bandeirante Fernão Dias Pais Leme, passaria à história como o principal responsável pela abertura da Estrada Real - o Caminho Novo, como foi popularmente chamado -, a mais importante rota de abastecimento e circulação de mercadorias para a região das Minas a partir do porto do Rio de Janeiro. Mas Garcia Rodrigues não foi apenas o homem do Caminho Novo; ele ficou também muito conhecido das autoridades portuguesas por conta de seu comportamento "próprio a paulistas", como não deixaria cuidadosamente de anotar, por exemplo, o ouvidor Caetano Costa Matoso em sua passagem pelas Minas durante o ano de 1749: ao mesmo tempo em que afirmava fidelidade e vassalagem perante o rei, mantinha uma postura independente, pródiga em soberba e em insolências (13).

Quanto a Manuel da Borba Gato, sem dúvida nenhum outro personagem do Setecentos mineiro evoca, ainda hoje, mais lendas em torno de si ou foi mais senhor dos recônditos segredos das Minas. E, certamente, seja por conta do assassinato de D. Rodrigo de Castelo Branco, então nomeado administrador geral das Minas pelo rei português, seja em decorrência da fuga espetacular que empreendeu depois do crime vivendo durante dezesseis anos embrenhado nas matas do Rio Doce, seja ainda como resultado das relações que manteve com os índios, relações que o transformaram numa espécie de "príncipe soberano entre os selvagens" (14), seja por tudo isso, o certo é que ninguém, além do Borba, sublinhou melhor a suposta autonomia e rebeldia dos paulistas a se submeterem a qualquer autoridade externa incluindo, no caso, as leis do reino e os representantes do rei.

No final do século XVIII mineiro, porém, o mundo desordenado e aventuroso dos paulistas existia apenas como recordação - era parte da história primordial das Minas. O tempo na capitania já era outro, pontuado pelo esforço de introjeção da norma, pela rigidez tributária, pela regularidade com que chegavam e partiam os governantes. Nesse cenário, o discurso das origens produzido pelo entrecho do poema Vila Rica é dúplice, sugerindo alguma coisa daquilo que Sergio Buarque de Holanda identificou, na poesia de Cláudio Manuel da Costa, como sendo o "sentimento ou,
10 Ver, por exemplo, a sugestão de Alfredo Bosi para o caso de Basilio da Gama. Alfredo Bosi, "As Sombras das Luzes na Condição Colonial", in Literatura e Resistência, São Paulo, Companhia das Letras, 2002

11 Cláudio Manuel da Costa, "Vila Rica", op. cit., p. 378

12 Respectivamente, Mariana, Ouro Preto e Sabará. Para governador Antonio de Albuquerquever: José loão Teixeira Coelho, Instrução para o Go verno da Capitania de Minas Gerais, Belo Horizonte, Funda ção João Pinheiro, 1994, pp. 125 e segs.; Charles R. Boxe A Idade do Ouro no Brasil São Paulo, Nacional, 1963 pp. 96 e segs.

13 Luciano Raposo de Almeida Figueiredo (org.). Códice Cos ta Matoso Belo Horizonte Fundação João Pinheiro 1999: Diogo de Vasconcellos, História Antiga de Minas Ge rais, Belo Horizonte, Itatiaia 1974, vol. 1

14 Luciano Raposo de Almeida Figueiredo (org.), op. cit. p. 188; Diogo de Vasconcellos op. cit. 
como se queira, o ressentimento do colonizado"(15). De fato, os mesmos versos que reconhecem a soberania do rei português sobre a região das Minas, legitimamente presente na autoridade do governador, não hesitam em acolher a mitologia paulista do desbravamento e em incorporar a ação autônoma desses mesmos paulistas - com toda a ambigüidade de características e renitência de comportamento face à autoridade régia - como impulso original e fundador na construção da identidade de Vila Rica:

"Se ao Paulista de fraco alguém acusa, Ele de seus espíritos só usa,

Quando a honra do empenho ao campo o [chama.

Não é valente, não, o que se inflama No criminoso ardor de a cada instante Dar provas de soberbo, e de arrogante. Os Europeus são fáceis neste arrojo" (16).

É certo que o poeta Cláudio Manuel da

15 Sergio Buarque de Holanda Capítulos de Literatura Coloni al, op. cit., p. 369

16 Cláudio Manuel da Costa, "Vila Rica", op. cit., p. 417.

17 Sobre recursos e estratégias literárias da poesia de Cláudio Manuel da Costa ver, por exem plo: Melânia S. de Aguiar, O Jogo de Oposiçōes na Poesia de Cláudio Manuel da Costa Belo Horizonte, UFMG, 1973 (mimeo.); Reinaldo M. Mar ques, Poetas e Poesia Inconfidentes: um Estudo de Arqueo logia Poética, Belo Horizonte, UFMG, 1993 (mimeo.).

18 Para Luís de Meneses ver, por exemplo: Laura de Mello e Souza, "Os Nobres Governadores de Minas; Mitologias Histórias Familiares", in Norma e Conflito; Aspectos da Histó ria de Minas no Século XVIII Belo Horizonte, Editora UFMG 1999, p. 188.

19 Cláudio Manuel da Costa "Ode; o Parnaso Obsequioso" in Domício Proença Filho (org.) op. cit., p. 331

20 ldem, "Carta Dedicatória", in Domício Proença Filho (org.l op. cit., p. 357

21 Ver, por exemplo: Sergio Buarque de Holanda, Capítulos de Literatura Colonial, op. cit.: Erns T. Kantorowicz, Os Dois Cor pos do Rei: um Estudo sobre Teologia Polífica Medieval, São Paulo, Companhia das Letras, 1998 uma homenagem, por vezes remunerada, a um personagem superior e protetor - no caso do Vila Rica, o conde de Bobadela. Homenagem oblíqua, todavia, já que seu significado vai escorregar furtivamente do louvor à figura do conde para fazer passar ao leitor outro objeto de exaltação: "Poema da fundação de Vila Rica, Capital das Minas Gerais, minha Pátria” (20).

Não era pouca coisa. É bem verdade que o tema da pátria vai aparecer com freqüência cada vez maior, na poesia do Setecentos, pelo menos desde quando $\mathrm{Ma}$ nuel Botelho de Oliveira, ainda no século XVII, tratou de apresentar sua Ilha da Maré como um resumo ambicioso e grandiloqüente do Brasil inteiro. Mas, tanto no seu caso, quanto no exemplo de poetas bem mais inspirados que se seguiram a ele, como Santa Rita Durão ou Basílio da Gama, pátria era ainda empregado de modo restritivo, em sentido privado e estreitamente paroquial, como referência ao lar ou ao local de nascimento. Para além da defesa quase natural dessa exígua unidade territorial, o termo pátria não trazia ainda nenhuma outra conseqüência política e não abrigava, de qualquer modo, nenhum sentido público (21).

A utilização do termo pátria, no poema Vila Rica, todavia, sugere que ocorreu uma mudança significativa do eixo da vida pública, nas Minas, durante a segunda metade do século XVIII, mudança importante na constituição de uma imaginação republicana. Herdeiro de uma raiz renascentista, de fundo petrarquista, que no entanto remonta à tradição da Antigüidade clássica, Cláudio Manuel da Costa retomou, a seu modo, a associação entre o termo pátria e a idéia greco-latina da cidade para pensála como objeto de devoção política. Nos termos do poema, essa estreita associação distinguia Vila Rica com um formato singular, ligado à caracterização de um lugar público, vale dizer, um lugar palpável, seguro e duradouro, capaz de acolher a memória dos feitos e das aventuras dos fundadores que o poeta fixara no poema e tornála permanente, de modo a ser transmitida à posteridade na sequiência das gerações. 
Aos olhos do poeta, apenas uma cidade capaz de agasalhar a memória da fundação das Minas poderia ser articulada a um determinado senso de pátria que não se mede com fronteiras ou canhões mas com a possibilidade de existência de um espaço onde homens livres e iguais conseguem encontrar-se a qualquer hora (22). A rigor, somente essa estreita associação entre pátria e cidade, presente no poema, faria da capital das Minas um lugar diferente de outros povoamentos da capitania, uns mais belos, como São João del Rey, outros, infinitamente mais ricos, como no caso do arraial do Tejuco. Haveria, em Vila Rica, a presença de alguma coisa própria da condição citadina e, ao mesmo tempo, singularmente distinta do sentido material urbano que caracterizava a trajetória da cidade - algo para além tanto da condição de aglomeração demográfica densa e diversificada erguida como ponta de lança sobre a exploração do ouro, quanto da função, bem mais complexa, de constituir o principal núcleo administrativo gerado pelo estado português para fixar o aparato burocrático metropolitano, na região das Minas.

Assim, no referente a Vila Rica, sua principal diferença estava no fato de que, na cidade antes sonhada e já então criada pela imaginação do poeta, um homem poderia desejar viver uma vida pubblica, definida a partir de um agregado de valores políticos, religiosos, éticos, estéticos e morais que terminavam invariavelmente formando laços peculiares próprios à constituição de um mundo de interesses comuns. Não por acaso, no décimo canto do poema, Cláudio Manuel da Costa tratou de completar essa visão da cidade pátria, até então ainda apenas entrevista, por uma última cena, dessa vez literal, de fundação: as armas e o brasão real entalhados em pedra ocuparam finalmente o centro da praça, ergueu-se o Pelourinho onde seriam anunciados os decretos do rei e açoitados publicamente escravos, cresceram grossas e altivas as paredes do casarão de pedra-sabão, alvenaria e madeira onde se instalaria a Casa de Cadeia e Câmara - estrutura vital da administração portuguesa para todo o império e, simultaneamente, único instrumento de representação dos interesses locais e do bem-estar público.

Ainda assim, Cláudio Manuel da Costa não parecia muito confiante em erigir uma cidade que tinha em mira defender e realçar somente a qualidade das instituições portuguesas e do maquinário de governo, provavelmente porque, aos olhos renascentistas do poeta, os vínculos ativos de Vila Rica com seus habitantes, vínculos capazes de apontar como referência a utilidade dos bens públicos e o espírito e a perspectiva dos homens que se dedicaram a construí-los, são talvez o traço que mais precisa ser visto. Não por acaso, no décimo e último canto do poema, a grandeza da cidade assumiu também o sentido concreto e quase pedagógico de fazer surgir, num lugar físico bem determinado, um ambiente arquitetônico de natureza pública que precisava abrigar os homens e lhes oferecer condições para uma vida melhor: só então aparecem, nos versos do Vila Rica, as fontes e os chafarizes de mármore que dão conta do abastecimento de água, as muitas pontes que ampliam o quadro de serviços e o equipamento urbano, a Torre do Relógio marcada pela qualidade do padrão construtivo das Minas, os templos magníficos “em que se hão de esgotar tantos erários” (23).

Para um poeta como Cláudio Manuel da Costa, que compôs uma obra em que dominou, insistente e angustiada, a intenção de expatriar-se na própria terra natal, o senso de pátria não poderia mesmo esgotar-se apenas no reconhecimento do lugar onde se nasce. Apesar disso, Vila Rica era uma visão patriótica ainda a ser completada, com novos acentos menos heróicos, talvez, e mais próximos do cotidiano dos homens comuns. Faltava, quem sabe, ao próprio poeta, que tanto se lamentara, na juventude, do exílio a que se vira fadado nesse cenário de barbárie americana e em meio a tanta gente inculta, descobrir que a pátria é um bem que só pode ser adquirido em comum e o patriotismo, naquela época, um termo comumente subversivo em suas conotações.

Mas essa descoberta não iria demorar muito tempo. Ainda em 1768, Cláudio
22 Para a relação entre patriotismo republicano e o conceito de pólis, ver: Maurizio Viroli Per Amore della Patria. Patriottismo e Nazionalismo nella Storia, Roma, Laterza 2001: Quentin Skinner L'Artiste en Philosoph Politique op cit. Hannah Arendt, O que É Política?, Rio de Janeiro, Bertrand Brasil, 1998

3 Cláudio Manuel da Costa "Vila Rica", op. cit., p. 443 para as características de uma arquitetura republicana, ver especialmente: Carlos Antônio Leite Brandão, "A República da Arquitetura". Newton Bignotto, "Três Maneiras de se Criar uma Cidade", op. cit. 
Manuel da Costa instalou, em Vila Rica, a Arcádia Ultramarina, um nome imponente para o que pretendia ser, no coração das Minas, uma associação de letrados e poetas congregados em serões cultos e interessados em declamar rimas pastoris - uma espécie de filial ou "colônia", para usar a expressão de Sergio Buarque de Holanda, da Arcádia Romana, o grêmio árcade italiano, criado em 1690, em homenagem à rainha Cristina da Suécia, que costumava reunir nos salões do palácio Corsini, em Roma, um grupo variado de amigos aristocratas, literatos, poetas e intelectuais e ao qual, na verdade, ao contrário de Basílio da Gama, Cláudio Manuel da Costa pode não ter sido nunca formalmente admitido (24).

É fora de dúvida, porém, que a Arcádia Ultramarina surgiu de uma combinação muito prosaica de interesses: com ela e com uma boa dose de métrica encomiástica, Cláudio Manuel da Costa pretendia saudar a posse do conde de Valadares como governador da capitania das Minas, aclamálo como protetor de sua academia e garantir para si as boas graças do novo governante. Deu certo: em 1769, ele foi confirmado nas funções de secretário de governo das Minas, cargo que lhe dava várias regalias especiais - como, por exemplo, a de sentar-se em cadeira rasa em todos os atos públicos do governador - e que irá manter até 1773 .

Ainda assim, mesmo envolvido com as luzes do cálculo e do interesse, talvez o poeta cuidasse de encontrar, também, com a ajuda de sua Arcádia, a possibilidade de um mundo posto nas margens do Ribeirão do Carmo não menos poético do que havia conhecido, em seus tempos de estudante, na beira do Tejo e do Mondego. E, é bem provável, talvez estivesse igualmente muito interessado em procurar companhia, gente com quem se comunicar em torno de idéias, projetos e inclinações literárias, outros companheiros de conversas para além das maledicências e intrigas que certamente animavam o cotidiano dos moradores das colinas sobre as quais se espalhava Vila Rica.
Pode-se imaginar que encontrar essa gente não foi uma tarefa especialmente fácil. De todo jeito, alguns desses companheiros, o poeta descobriu fora da região das Minas: Basílio da Gama andara muito provavelmente pela capitania, onde tinha a família, em 1768, e parece fora de dúvida que, durante essa estada, chegou a encontrar-se ou fazer algum tipo de contato com Cláudio Manuel da Costa; Silva Alvarenga, mineiro de nascimento e gosto literário afim, iria se estabelecer no Rio de Janeiro, em 1777. Além disso, pelo menos desde 1759, o próprio Cláudio Manuel da Costa era sócio da Academia Brasílica dos Renascidos, fundada na Bahia, uma das várias associações literárias que surgiram no Rio de Janeiro e em Salvador, a partir de 1724, e com a qual manteve correspondência durante boa parte de sua vida (25).

Contudo, a Arcádia Ultramarina é Cláudio Manuel da Costa, como quer Sergio Buarque de Holanda, "e é ele tão-somente" (26). Mas, passados mais alguns anos, o poeta conseguiria enfim realizar, em Vila Rica, serões realmente muito animados: em 1775, Alvarenga Peixoto foi nomeado ouvidor da comarca do Rio das Mortes e Domingos Vidal de Barbosa Lage voltaria a Minas para fixar-se em Juiz de Fora; Luís Vieira da Silva, proprietário de uma livraria formidável, já se tornara cônego erudito em Vila Rica e Carlos Correia de Toledo transformara-se no vigário apreciador de música da vila de São José del Rey; João Rodrigues de Macedo terminara, por fim, seu sobrado, em Vila Rica, construção admirada em toda a capitania, e José Álvares Maciel acabara de regressar a Minas trazendo na bagagem vários livros, inclusive um do abade Raynal comprado barato na Inglaterra - cuidando, inclusive, "que tinha feito grande compra" (27); Domingos de Abreu Viera há muito era cliente de Cláudio Manuel da Costa nas questões legais relativas ao contrato dos dízimos e o tenente-coronel Francisco de Paula Freire de Andrade continuava a desfilar sua fidalguia bastarda à frente dos destacamentos dos Dragões de Minas. Apesar disso, somente em 1782 os serões do poeta esta- 
riam finalmente completos: Tomás Antônio Gonzaga, com quem Cláudio Manuel da Costa se ligaria em estreita amizade, fora finalmente despachado ouvidor e procurador de defuntos e ausentes na comarca de Vila Rica (28).

O hábito dos serões funcionava como uma prática comum de sociabilidade urbana na segunda metade do século XVIII era perfeitamente convencional, na época, homens que se visitam de modo regular e informal para conversar, declamar versos, ouvir música ou jogar gamão. No caso dos membros do círculo de Cláudio Manuel da Costa, pela qualidade da poesia que produziam, provavelmente a literatura - e os projetos literários que quase todos afagavam - foi tema mais importante, no geral, do que filosofia ou política. Além disso, em virtude da boa acolhida que esse círculo recebeu de D. Rodrigo José de Meneses e Castro, sucessor do conde de Valadares no governo da capitania, ou de sua esposa, D. Maria José Ferreira d'Eça e Bourbon - que, juntamente com o filho, nascido nas $\mathrm{Mi}$ nas, seria transformada em alvo de églogas, sonetos e cantos por parte de Cláudio Manuel da Costa, Gonzaga e Alvarenga Peixoto -, algumas dessas reuniões realizaram-se em pleno palácio, com a sociedade da terra sendo chamada a dar o devido apreço aos versos de seus poetas (29).

Contudo, quando os tempo mudaram, de maneira radical, com a chegada de um outro Meneses para o governo das Minas D. Luís da Cunha Meneses -, as suscetibilidades foram feridas pela distribuição de privilégios a uma nova turma de cortesãos e de patentes de oficiais a militares pardos; os interesses particulares terminaram profundamente contrariados com a remoção, sem qualquer cerimônia, da elite branca da terra dos postos lucrativos da administração local para ceder lugar aos favoritos do governador; a rede do contrabando sofreu brusca perturbação com a entrada em cena de outro grupo de especuladores e o descontentamento começou a grassar (30). A partir de então, parece fora de dúvida que o hábito dos serões prosseguiu animado na larga varanda de Gonzaga, na espaçosa sala de Cláudio Manuel da Costa, entre as cortinas de damasco do sobrado de Francisco de Paula Freire de Andrade ou antes da ceia em casa de João Rodrigues de Macedo, mas os assuntos do dia tornaram-se menos líricos, o espírito dos homens mais desassossegado, os versos e as opiniões mais suscetíveis ao juízo político e os acontecimentos da Europa e da América Inglesa surpreendentemente mais próximos do cotidiano da gente das Minas.

O círculo reunido em torno de Cláudio Manuel da Costa não foi o primeiro nem seria o único momento de expressão de descontentamento político da capitania. Durante praticamente todo o Setecentos, falou-se em motins, sedições, contestações e levantes na região das Minas. Além disso, seja por força dos mecanismos de controle da ordem interna ou dos processos de extorsão tributária metropolitana, seja como decorrência das relações entre brancos e negros e da ameaça representada pela presença do vadio itinerante e biscateiro ou do quilombola fugitivo, seja ainda por conta da generalização dos crimes produzidos no âmbito das relações pessoais, na prática, a população mineira se viu obrigada a desenvolver uma imensa capacidade para conviver com a violência, no seu cotidiano (31).

A partir de meados do século XVIII, porém, as revoltas perderam seu caráter espetacular e tornaram-se surdas, disseminadas, constantes (32). A própria natureza das Minas inclina ao tumulto e persuade às revoltas, diria, convicto, o conde de Assumar, quando tentou, a todo custo, justificar a execução sumária e o esquartejamento de Felipe dos Santos como parte das medidas de repressão ao motim de 1720 em Vila Rica. E explicava: "a terra parece que evapora tumultos; a água exala motins; o ouro toca desaforos; distilam liberdades os ares; vomitam insolências as nuvens; influem desordem os astros; o clima é a tumba da paz e berço da rebelião; a natureza anda inquieta consigo, e amotinada lá por dentro, é como no inferno" (33).

Entretanto, se é possível dizer que, pelo menos desde 1707, desde os emboabas, como quer o poema Vila Rica, falava-se
28 Para um perfil intelectual dos inconfidentes ver, por exemplo: Brito Broca, "O Ambiente Literário de Vila Rica na Epoca da nconfidência", in Revista MEC, 35, 1966, pp. 19-24 Antonio Candido, "Letras déias no Período Colonia" in Literatura e Sociedade, São Paulo, Nacional, 1976 Wilton Cardoso, "As Letras Mineiras no Século XVIII", in Primeiro Seminário de Estudos Mineiros, Belo Horizonte, UFMG, 1956

29 Para D. Rodrigo José de Meneses e Castro ver: Laura de Mello e Souza, "Os No bres Governadores de Minas; Mitologias e Histórias Familia res", op. cit.; Diogo de Vas concelos, História Média de Minas Gerais, Belo Horizonte, Itatiaia, 1974

30 Para D. Luís da Cunha Me neses, ver: Kenneth R. Maxwell A Devassa da Devassa; a In confidência Mineira: BrasiPortugal- 1750-1808, Rio de Janeiro, Paz e Terra, 1977.

31 Fazem parte desse quadro, por exemplo, os levantes de Vila do Carmo (1713): Sabará Vila Nova da Rainha Vila Rica e Vila do Carmo (1715): Ca tas Altas (1717-18): Pitangui (1717-20); Vila Rica (1720) São Francisco (1736); Campanha (1746) e Curvelo (1776). A esse respeito, ve especialmente: Carla Anasta sia, Vassalos Rebeldes: Violência Coletiva nas Minas na Pr meira Metade do Século XVIII Belo Horizonte, C/Arte 1998

32 Ver, por exemplo: Laura de Mello e Souza, Desclassifica dos do Ouro; a Pobreza Mineira no Século XVIII, Rio de Janeiro, Graal, 1982.

33 Discurso Histórico e Político sobre a Sublevação que nas Minas Houve no Ano de 1720 Belo Horizonte, Fundação João Pinheiro, 1994 , p. 59 
em revolta nas Minas, é também muito provável que o círculo reunido em torno de Cláudio Manuel da Costa tenha introduzido algumas novidades importantes nesse contexto. Uma delas, talvez a mais evidente: propiciar a emergência de uma rede de comunicação e sociabilidade política que se estendeu pelo interior, atingiu as três comarcas mais importantes da capitania comarca de Vila Rica, comarca do Rio das Mortes, comarca do Serro do Frio - e teve como referência matriz o círculo de vassalos letrados de Vila Rica, reunido a partir da figura de Cláudio Manuel da Costa.

Contudo, a principal característica dessa rede de sociabilidade política foi decorrência de sua capacidade de fluir e de se espraiar para diferentes espaços de vida social nas Minas. Com essa novidade, entrou em circulação um processo de difusão de idéias e de opiniões que, desde seu início, foi convergente aos grupos de elite local, caracterizando-os como expressões de uma cultura política de formato alternativo, de traço mais ou menos consistente, mais ou menos radical, mas invariavelmente dependente do quadro de interesses em jogo.

Na comarca do Rio das Mortes, por exemplo, personagens envolvidos com essa rede chegaram, em diversos momentos, a exercitar idéias incendiárias, de teor bastante radical, mas com conduta propriamente política sempre orientada pela utilidade de tais idéias dentro de uma conjuntura de interesses próprios. Região de economia mais equilibrada e diversificada, sustentada em terras agricultáveis e pastoris e para onde já se deslocava a concentração dos recursos econômicos da capitania, não por acaso, no final do século XVIII, no Rio das Mortes, o peso do trabalho escravo, como valor econômico predominante, começara a diminuir progressivamente, embora ainda fosse um importante componente de riqueza. Por essa razão, ao contrário do que ocorreu no resto da capitania, a possibilidade da abolição da escravidão e a incorporação de escravos armados como parte de uma estratégia militar sediciosa foram, de fato, uma questão considerada sob o ponto de vista político, por membros da elite lo- cal, como Alvarenga Peixoto ou padre Toledo, durante os serões sediciosos de São João del Rey e São José del Rey (34).

Mas essa rede de sociabilidade também desdobrou-se verticalmente pelo interior da capitania alcançando outras esferas da sociedade local. Na prática, isso traduziu a peculiaridade de uma cultura política emergente que, mesmo preservando o peso das diferenças e condições sociais, não era de modo algum excludente; ao contrário, demonstrava ser capaz de generalizar um sistema de referências políticas alternativo, passível de reconhecimento por uma audiência ampla, qualquer que fosse seu nível social ou cultural.

Talvez a possibilidade de reconhecimento dessas referências por um público diversificado tenha sido viável por conta das facilidades de identificação desse público com um mecanismo inerente à constituição da própria rede, um mecanismo que foi disparado, na sua origem, pela presença de uma combinação de motivos nada virtuosa orientando a ação de seus participantes. O mais importante desses motivos: a existência de um conjunto muito variado de interesses contrariados pela administração portuguesa, na região das Minas, ao final do século XVIII, servindo para tornar diferentes grupos da sociedade mineira que jamais haviam lido um tratado político cada dia mais sensíveis quanto ao seu status colonial dentro do império português - interesses capazes de gerar, portanto, ao menos na opinião de Tomás Antônio Gonzaga, boa parte das condições "em que se alteram os ânimos dos vassalos" e se produzem, por via de conseqüência, "a ocasião mais oportuna para um levante" (35).

De certo modo, então, a rede de sociabilidade política que emergiu das Minas setecentistas ganhou os caminhos da capitania sobretudo por estar preocupada com o direito aos bens e sobre os bens distribuíveis e provavelmente por conta disso alcançou locais inusitados. Todavia, ao contrário do que ocorreu com os procedimentos de comunicação e interligação política entre os serões de Vila Rica, São João del Rey e São 
José del Rey, que tinham os letrados por portadores, o processo de expansão vertical da rede foi ativado, sobretudo, pela ação de personagens que transitavam entre diferentes esferas de vida social, como acontecia, por exemplo, com o alferes Joaquim José da Silva Xavier, o Tiradentes, ou com o padre Rolim - o primeiro, antigo comandante do destacamento de cavalaria responsável pela patrulha da serra da Mantiqueira, era um visitante habitual nas pousadias, ranchos e estalagens do Caminho Novo e costumava transitar amiúde por boticas, praças e portas de igrejas existentes nas vilas em seu entorno, além de ser também um conhecido frequientador de tabernas e casas de prostituição; o segundo, notório contrabandista de diamantes, conhecia e se relacionava com gente de todo tipo, inclusive com boa parte dos garimpeiros e faiscadores fora-da-lei que infestavam as montanhas do Serro do Frio (36).

A realização de serões cada vez mais carregados de crítica política em Vila Rica e a emergência de uma rede de comunicação e sociabilidade que lhe ofereceu suporte para circulação de idéias e opiniões no interior da capitania certamente trariam conseqüências importantes no processo de formação de uma imaginação republicana nas Minas setecentistas. De fato, ainda que hesitante face ao primado das relações familiares e à hipertrofia da esfera privada, características que já dominavam as formas de sociabilidade na América Portuguesa, estava em curso a constituição de outras possibilidades de organização da vida em comum, possibilidades que incluíram, no cotidiano de seus participantes, a chance de ensaiar algumas novas experiências próprias ao mundo da política: a liberdade do falar um com o outro, a complexa tentativa de trocar opiniões sobre alguma coisa, a convicção de que as opiniões surgem onde quer que as pessoas se comuniquem livremente umas com as outras e sejam capazes de tornar públicos os seus pontos de vista (37).

Mesmo que os locais privilegiados por onde se experimentavam procedimentos de descoberta da cena pública, nas Minas, durante a segunda metade do século XVIII, ainda sejam originariamente locais de sociabilidade privada: a casa das pilatas, a hospedaria de João da Costa Rodrigues, na beira do Caminho Novo, a taverna do arraial de Matosinhos, as muitas residências particulares - como, por exemplo, a casa de Francisco Paula Freire de Andrade, de João Rodrigo de Macedo, de Cláudio Manuel da Costa, de Tomás Antonio Gonzaga, de Domingos de Abreu Vieira, de Vicente Vieira da Mota, em Vila Rica; a fazenda de Alvarenga Peixoto, a casa de João de Resende da Costa, em São João del Rey; a casa do padre Toledo, em São José del Rey (38).

A rigor, a vivência em ambiente privado dos procedimentos de descoberta da cena pública é um indicativo preciso tanto das condições de instabilidade da formação dessa cena nas Minas setecentistas, quanto do traço de ambigüidade que a constitui, traço que informa sobre a série de tensões que então mediava os limites entre a casa e as questões de interesse comum. Contudo, esse traço de ambigüidade é também revelador de certas vantagens individuais ou familiares com que se protegiam os freqüentadores do mundo público, vantagens capazes de transformá-los, ao mesmo tempo, em convidados bem postos de eventos domésticos, como batizados e casamentos, letrados maduros reunidos para cultivar a arte da conversação e a prática do versejar e participantes contumazes de reuniões sediciosas e de conversas escusas.

De fato, o próprio Tomás Antônio Gonzaga, já na prisão, procurou fazer uso, para sua proteção, das vantagens da ambigüidade que recobria a cena pública na capitania das Minas e, quando inquirido sobre o fato de comparecer com muita freqüência a esses serões, tratou de insistir, impávido, que neles apenas "conversavam em humanidades", tudo estava conforme com o convencional, nada haveria que reprovar. E completava, ardiloso: um desses serões, especialmente, "lhe lembra muito bem por repetir o coronel Alvarenga umas oitavas feitas ao batizado de um filho do excelentíssimo D. Rodrigo” (39).
36 Para Tiradentes ver, por exemplo: Autos da Devassa da lnconfidência Mineira, op. cit. vol. 5, p. 243; vol. 1, pp. 184 7. Carla Anastasia, "Salteadores, Bandoleiros e Desbrava dores nas Matas Gerais da Mantiqueira (1783-1786)" in Mary del Priori lorg. I. A Revisão do Paraíso, Rio de Janeiro Campus, 2000. Para padre Rolim ver: Roberto W. de Almeida, Entre a Cruz e a Es pada: a Saga do Valente Devasso Padre Rolim, Rio de Janeiro, Paz e Terra, 2002

37 Para mecanismos de articulação e passagem do mundo privado ao público, ver: Hannah Arendt, "Public Rigth and Private Interests: in Response to Charles Frankel" in Small Comforts for Hard Times: Humanists on Public Policy, Columbia, Columbia University Press, 1077 ; Hannah Arendt, O que É Poltica?, op. cit.; J. G. A. Pocock, Virtue, Commerce and History, Cambridge, Cambridge University Press, 1995

38 Autos da Devassa da Inconf dência Mineira, op. cit., vol. 1 pp. $157,168,173,183$ $1, p p .157,168,173,183$
$189,200-3,214,251$ : vol. 5, pp. $25,48,39,112,113$ $115,117,125,191,221$ 235-7, 328-30

39 ldem, ibidem, vol. 5, p. 223 
Gonzaga não explicou, apenas, durante os interrogatórios da Coroa, que as tais oitavas, compostas por Alvarenga Peixoto, faziam parte do Canto Genetlíaco, poema que combina, com particular empenho, temas da poesia áulica com o sentimento de apego à natureza americana, fazendo dela fundamento de uma ancestralidade instituída independente da portuguesa metropolitana, como já havia sugerido Cláudio Manuel da Costa, e algo mais do que um simples motivo para expansões líricas. Com efeito, no Canto Genetlíaco, é possível distinguir o traço já meio sedicioso por onde ecoa o espanto do poeta diante do poder que brotava da prata, do ouro e das pedras encontradas nas Minas, mas que mantinha miseráveis os mineiros. O mesmo traço também alimenta a veemência com que seus versos exprimem compaixão diante de uma qualidade social particular a um grupo de homens - homens pardos e pretos, tintos e tostados - reconhecidos, ao longo do poema, como capazes de fazer, com seu trabalho duro e com sua valentia, a riqueza dessa terra bastar-se a si mesma (40).

Alvarenga Peixoto é, ao que parece, o menos expressivo dos poetas setecentistas mineiros, em parte por conta de uma produção literária relativamente escassa para ser apreciada em sua inteira significação entre a poesia da época, em parte por apoiar sua métrica nos temas da poesia áulica, em parte, ainda, por exercitar uma escrita poética excessivamente voltada para apresentação e julgamento em academias e para competição em jogos florais com amigos. Contudo, nos serões letrados de Vila Rica e São João del Rey, seus versos, como os dos demais, funcionavam também como veículos privilegiados de expressão de projetos, opinião e emissão de juízo político coisa que Gonzaga reconhecia, apreciava, praticava e sabiamente tratou de ocultar no decorrer das quatro inquirições a que foi submetido pelas autoridades portuguesas.

A constituição e manifestação de opinião gerada pela realização dos serões e pela emergência de uma rede de comunicação e sociabilidade política foi, sem dúvida, outra conseqüência importante na for- mação de uma imaginação republicana, nas Minas, durante a segunda metade do século XVIII. Na prática, opiniões surgem onde e entre indivíduos que se comunicam livremente uns com os outros, graças ao relacionamento com iguais na publicidade de seus encontros, tornando públicos seus pontos de vista. Durante os serões mineiros setecentistas isso significou viver, por um certo período de tempo, um pouco da experiência da liberdade de externar opinião e do direito de ouvir opiniões de outros, exercício capaz de cobrir inclusive uma gama de conteúdos comumente muito subversivos em suas variações.

Com efeito, em uma reunião que ficou famosa, realizada em São José del Rey, em casa de padre Toledo, o debate que ocorreu, provavelmente muito animado, dava a perceber, no mínimo, os procedimentos adotados por um círculo de homens interessados em fazer transitar publicamente suas opiniões e passá-las através do crivo de um entendimento capaz de separar aquelas que são arbitrárias ou meramente idiossincráticas. Quaisquer que fossem seus motivos pessoais, isso constituía, certamente pela primeira vez, nas Minas, um público diretamente engajado no debate político e esse público era inclusive capaz de se expressar numa diversidade de sentimentos conflitantes, tal como ocorreu na reunião de São José del Rey: de um lado, a compaixão bem pensante de Alvarenga Peixoto face ao destino dos negros, compaixão que advogava a alforria dos escravos nascidos na colônia e se alimentava do receio da eclosão de uma revolta na capitania em que brancos, menos numerosos, estariam sempre em desvantagem; de outro lado, a ansiedade lógica de Álvares Maciel sobre um assunto de conteúdo excessivamente explosivo e de engenharia política complexa em toda a área colonial americana, ansiedade que o levava a emitir juízo de caráter rigorosamente utilitário, regido pela convicção de que o ideal da abolição, na conjuntura das Minas, era não só uma fantasia tola, mas uma receita para o desastre - sem mão-deobra escrava, insistia Maciel, "os serviços nas Minas ficariam muito mal” (41). 
$\mathrm{Na}$ América Inglesa, às vésperas da Revolução Americana, esse público foi formado por uma literatura política muito variada composta pela proliferação de artigos, folhetos, pequenos ensaios, sermões e sobretudo panfletos, cujos autores eram, no geral, homens desconhecidos, sem competência ou autoridade particular para tomar a palavra e emitir opinião política (42). Nas Minas setecentistas, porém, foram principalmente os versos produzidos por letrados e os livros adquiridos por eles, na Europa, que funcionaram como principal suporte para formação e circulação de opinião. Na realidade, isso ocorreu, em parte, porque era hábito dos letrados reunirem-se para leitura coletiva de textos de interesses comum; mas, em parte, também, porque, objetivamente, livros circulavam em Minas pelo menos desde a primeira metade do século XVIII; e, em parte, ainda, porque esse era um espaço de vida pública onde não havia acontecido uma interação entre o registro oral e escrito, mas o predomínio de uma sociabilidade política associada ao registro oral mesmo quando a circulação das idéias ocorria através da palavra impressa (43).

Entre os poetas reunidos pelo círculo letrado de Vila Rica, Tomás Antônio Gonzaga foi, provavelmente, o participante mais ativo na geração desse processo de formação e circulação de opinião sustentado pela prática do versejar. A rigor, é bastante provável que essa característica seja uma das conseqüências possíveis do tipo singular de poesia que praticou. Não por acaso, foi Gonzaga, entre os poetas mineiros, quem primeiro experimentou introduzir nos seus versos a ousadia de certas expressões muito particulares ao cotidiano das Minas como, por exemplo, bateia, capoeira, cascalho, expressões que ajudaram a fornecer à sua poética um timbre caracteristicamente local, particularmente realista e sobretudo de fácil trânsito entre diversos extratos sociais:

“Tu não verás, Marília, cem cativos Tirarem o cascalho e a rica terra. Ou do cerco dos rios caudalosos Ou da mina da serra.

\begin{abstract}
Não verás separar ao hábil negro Do pesado esmeril a grossa areia E já brilharem os granitos de ouro No fundo da bateia" (44).
\end{abstract}

Com efeito, existe nos versos de Gonzaga, diferente do que acontece com a linguagem curiosamente híbrida dos poemas da maturidade de Cláudio Manuel da Costa, a presença e a solicitação de um mundo americano, muito humano, que desliza de modo espontâneo e, por vezes, sub-repticiamente, para dentro da paisagem idílica e da singeleza amaneirada dos árcades. Por conta desse movimento, há uma agilidade e uma leveza nos versos curtos que o poeta misturou aos longos num mesmo poema para quebrar com sua monotonia rítmica e há uma história de amor que se confunde e que importa para compreensão de sua obra poética (45). Mas há, também, nos versos de Gonzaga, um certo deslocamento do olhar que escapa ao centro, recai sobre as Minas e circula inquiridor por Vila Rica, a cidade onde proliferam "tabernas fedorentas" em cujas prateleiras se amontoam "os queijos, a cachaça, o negro fumo"; onde o vento corta "em largas fitas" as folhas das bananeiras e o sol de outubro carrega consigo nuvens de tanajuras, "formigas que criam com as chuvas, longas asas" (46).

Provavelmente graças a esse olhar inquieto foi Gonzaga quem, de certo modo, retomou, de Cláudio Manuel da Costa, um pouco da arte de fundar cidades para recortar, em meio ao equipamento urbano de Vila Rica, os acontecimentos humanos que poderiam lhe oferecer legitimidade. Nas Cartas Chilenas, poema que, talvez não por acaso, muito possivelmente contou com uma demão de Cláudio Manuel da Costa na fixação de alguns temas e no aprimoramento dos versos, os locais públicos de Vila Rica estão sempre fervilhando contaminados pelo burburinho de seus habitantes nas ruas e pelas múltiplas e tumultuadas funções da vida citadina.

Assim, em meio a todo esse movimento, negros domesticados à força de temor ergueram as grossas paredes da Casa de Cadeia e Câmara, brancos e mestiços va-
42 Para a literatura política da Revolução Americana ver: Bernard Bailyn, The ldeological Origins of the American Revolution, Boston, Harvard University Press, 1975.

43 Para o predomínio do registro oral ver, por exemplo: Antonio Candido, Literatura e Sociedade, op. cit.; para circulação de livros nas Minas do século XVIII, ver: Eduardo Frieiro, $\mathrm{O}$ Diabo na Livraria do Cônego, São Paulo/Belo Horizonte, Edusp/Itatiaia, 1981; Júnia Furtado, O Livro da Capa Verde: o Regimento Diamantino de 1771 e a Vida no Distrito Diamantino no Período da Real Extração, São Paulo, Annablume, 1996.

44 Tomás Antonio Gonzaga, "Lira III", in Domício Proença Filho lorg.l, op. cit., p. 686; ver também: Sergio Buarque de Holanda, Capítulos de Liferatura Colonial, op. cit.

45 Vale lembrar que Gonzaga é, depois de Camões, o poeta lírico mais lido na língua portuguesa ainda que a frequêencia nas edições tenha diminuído a partir de 1960. A esse respeito, ver: Otto Maria Carpeaux, Pequena Bibliografia Crítica da Literatura Brasileira, Rio de Janeiro, Letras e Artes, 1964, p. 56. Para Gonzaga ver, por exemplo: Antonio Candido, Formação da Literatura Brasileira, op. cit.; Eduardo Frieiro "Como Era Gonzaga?", in O Diabo na Livraria do Cônego op. cit.; Alfredo Bosi, História Concisa da Literatura Brasileira, op. cit.; Reinaldo Martiniano Marques, op. cit.

46 Tomás Antonio Gonzaga "Cartas Chilenas; Carta Quinta e Décima Segunda" e "Lira IX", in Domício Proença Filho (org.), op. cit., pp. 828, 888; p. 587 . 
dios perambularam por becos e ladeiras íngremes para escapar de maus-tratos, um mulato tocou rabeca nos festejos desponsoriais do infante D. João com a princesa de Espanha, D. Carlota Joaquina, taberneiros, tendeiros e negras quitandeiras enriqueceram com o ouro que já fora fácil, sapateiros, alfaiates e almocreves sonharam ingressar em corporações militares para, um dia, alcançarem outra posição social. Ao contrário do desenho absolutamente deserto da praça, das ruas e dos edifícios, com que Cláudio Manuel da Costa fundou Vila Rica, existe um bulício de pólis na representação citadina de Gonzaga que deixa sempre aflorar uma certa intenção, trai sempre um certo artifício, algum cálculo ou malícia do poeta - e parece sublinhar, por meio desse olhar inquieto, eventualmente moralista e meio aristocrático, que desliza quase desatento pelas cavalhadas, pelas procissões, pelas peças levadas em cena na Casa de Ópera ou pela profunda mestiçagem que envolveu todos os extratos sociais da capitania no quente lundum e no vil batuque, os vínculos ativos de Vila Rica com seus habitantes (47).

De uma certa maneira, então, o olhar de Gonzaga pensa; e nas Cartas Chilenas, parece interrogar a superfície de Vila Rica especialmente para indicar a máscara, o jogo, a bufonaria, a burrice satisfeita, por trás, acima, além dela. É certo que o efeito de desmascarar tinha nesse poema um alvo específico: o discurso político e as práticas administrativas de D. Luís da Cunha Meneses, governador da capitania. É certo também que Gonzaga possuía motivos pessoais de sobra para se opor a Cunha Meneses, incluindo, no caso, a perda dos privilégios para cobrança de dívidas e execução de hipotecas e da parte que lhe cabia nas até então lucrativas relações entre a magistratura mineira e o comércio ilegal do ouro e dos diamantes (48). Vistas por esse ângulo, as Cartas Chilenas são sobretudo o resultado, em verso e rima, de um esforço razoavelmente bem-sucedido de desmoralização do governador e de seus favoritos na administração da capitania - além de funcionarem, é claro, como uma forma muito elaborada de panfleto político, de linguagem saborosa, rápida, cortante e sem precedentes nas Minas setecentistas.

Mas as Cartas Chilenas são também o momento de zombaria de Gonzaga, o momento em que o poeta tratou de explorar as conexões entre o riso e o desprezo, herdadas da cultura retórica italiana renascentista, para atingir com o ridículo tudo aquilo que, nas Minas, pretendia impor-se unicamente por meio da força e da autocracia (49). Com efeito, o riso proposto pelo poema é basicamente uma expressão de sarcasmo e de escárnio diante de coisas ridículas e tudo que é ridículo, insiste Gonzaga - o plebeísmo de Cunha Meneses, a charlatanice e a venalidade de seus auxiliares, a degradação dos costumes, o farisaísmo dos padres -, é desonesto. Diante disso, é muito provável que o poema não trate apenas de avaliar as condições para formulação de uma crítica decidida a escarnecer tanto do mando exercido por alguns homens desprezíveis, quanto da submissão experimentada por uma sociedade decadente totalmente de acordo com aquilo que a mistifica - nas Cartas Chilenas, o riso vai além e debocha do vício.

Esse establishment que o riso de Gonzaga condenou não era nem absurdo nem injustificável essencialmente; era um establishment de falsificação de valores. Aos olhos do poeta ele era injusto, vale dizer, desobediente às injunções dos princípios originais de justiça e de razão sob os quais deveria ser sustentada a autoridade autêntica. Nas condições históricas em que Gonzaga compôs sua antinomia virtude versus corrupção para o entrecho das Cartas Chilenas, reencontrar a virtude curiosamente pressupunha uma volta para trás, era alguma coisa para a qual se remonta, algo que se encontra como fundamento na origem de uma sociedade.

Evidentemente, Gonzaga podia ser apenas mais um magistrado que compartilhava da leitura de livros como a História Filosófica das Duas Índias, do abade Reynal, com Domingos Vidas Barbosa, com Álvares Maciel ou com o cônego Luís Vieira da Silva, e se preocupava com uma história de espoliação e pilhagens que não oferecia 
politicamente nada às instituições da América Portuguesa e a seus princípios além da ocasião para se degenerar. Mas, com certeza, a sua não era uma opinião isolada: no século XVIII, aos olhos dos homens que protagonizaram a Revolução Americana e a Revolução Francesa, em seus estágios iniciais, a verdadeira ação revolucionária não poderia ser senão uma ação restauradora, uma restitutio ad integrum, para usar o argumento e a linguagem de Montesquieu (50).

As interpretações de Montesquieu acerca de um Estado livre marcaram fortemente a imaginação política da América Inglesa muito antes de atingir a França revolucionária e, ao que se sabe, alcançaram influência sobre as opiniões de alguns dos personagens que participaram ou circularam em torno do grupo de letrados de Vila Rica e de São João del Rey, como o próprio Gonzaga ou o cônego Luís Vieira da Silva (51). Contudo, ao contrário do que ocorreu no decurso da Revolução Americana, esses personagens, contra sua vontade, não chegaram com sua ação política a atingir um ponto sem retorno a partir do qual veio à tona a expectativa do enorme pathos de uma nova era contido na palavra "revolução", com seus significados associados de ruptura, mudança irreversível, começo e violência (52).

Assim, até onde os letrados mineiros lograram acompanhar os acontecimentos da América Inglesa, o término e a meta de seu propósito político consistiam na restauração do antigo direito, num movimento de retorno à autoridade da lei. Em boa medida, esses homens tratavam, nas Minas, do problema político da corrupção e sobre as maneiras conhecidas de tornaressa sociedade capaz de se reencontrar, de bom grado ou à força, com o bom governo, com uma ordem pública regida por leis que impedissem o descomedimento dos homens e das instituições. Corrupção, na linguagem do século XVIII, significava venalidade $e$ perturbação das condições políticas necessárias para o exercício da virtude e da liberdade do homem (53) e, por essa razão, tanto poderia corroer o equilíbrio do parla- mento inglês, como acusavam os americanos, quanto provocar uma utilização rigorosamente privada da autoridade pública eliminando, em última análise, quaisquer direitos às coisas e sobre as coisas, como denunciavam os letrados mineiros.

Em ambos os casos, porém, os dois lados da América estavam empenhados na descoberta de uma estratégia política de retorno aos princípios originais. Como parecia intuir, por exemplo, o alferes Joaquim José da Silva Xavier, nenhum daqueles homens parecia ansioso por coisas novas, não se tratava de propor um início ou a criação de algo inteiramente novo; tratavase, antes, de garantir uma volta ao princípio, de restaurar uma antiga ordem de leis inscritas na natureza das coisas que fora perturbada e violada pelo despotismo de monarcas absolutos, por abusos do governo colonial ou por ambas as situações. À maneira de todos os outros revolucionários do século XVIII, Tiradentes também não estava preparado para desencadear alguma coisa sem precedentes. E repetia, insistente, aos seus interlocutores: "não diga levantar, diga restaurar" (54).

Apesar disso, é possível especular que a forma política república atraiu os letrados mineiros menos em razão de uma provável associação entre a natureza do republicanismo e a idéia de virtude significando devoção à pátria e ao bem público, como sugeriu Montesquieu, e muito mais em decorrência de sua vocação essencialmente contrária ao princípio monárquico absolutista. Com efeito, é uma certa concepção de liberdade que lhes importava e ela não aparecia associada nem à virtude ideal dos antigos, como produto de uma forte motivação cívica, nem ao caráter igualitário dos modernos, conseqüência de uma possível equiparação de república a governo democrático, idéia mais convincente, aliás, se aplicada ao século XIX. Os homens que participaram ou circularam em torno do grupo de letrados de Vila Rica e de São João del Rey deixaram atestado seu gosto pela estabilidade e pareciam desejar a liberdade sobretudo para cuidar de seus próprios assuntos.
50 Ver especialmente: Montes quieu, Do Espírito das Leis, São Paulo, Abril Cultural, 1979.

51 Para as leituras dos inconfidentes ver, por exemplo: João Pinto Furtado, op. cit.

52 Para essa consciência de um retorno e o significado da palavra revolucão no século XVIII ver: Reinhart Koselleck, Future Past: on the Semantic Historical Time, Cambridge MIT Press, 1985. Hannah Arendt, Da Revolução, op. cit

53J. G. A. Pocock, Virtue, Com merce and History, op. cit.

54 Autos da Devassa da Inconfidência Mineira, op. cit., vol. 1 , pp. 104 e 152 
A rigor, vinha daí o valor que emprestavam à idéia de república, valor baseado principalmente na relação que essa tópica manteve com determinadas características particulares a um tipo muito específico de cidade - a cidade que adquiriu a liberdade de administrar seus próprios assuntos. $\mathrm{Na}$ realidade, o ponto de partida para a sensibilidade republicana da maior parte desses homens estava no ideal de cidade que eles tomam em seu sentido político tradicional, tão caro ao republicanismo anglo-americano, significando independência mais autogoverno.

De fato, os letrados mineiros, como, por exemplo, Luís Vieira, Álvares Maciel, Carlos Toledo e Domingos Vidal Barbosa, haviam aprendido com a experiência histórica da América Inglesa, em especial com a leitura de Recueil de Loix Constituitives des États-Unis de l'Amérique, que incluía os Artigos da Confederaçãoe das constituições de Pensilvânia, Nova Jersey, Delaware, Maryland, Virgínia, Carolinas e Massachusetts, algumas coisas sobre a política da liberdade, como se costumava dizer à época da Revolução Americana. Haviam aprendido mais especificamente, por exemplo, que o poder estava na periferia, nos diversos estados soberanos, livres e independentes; ou então que esse poder se concentrava nos legislativos e, em particular, nas câmaras baixas; ou, ainda, que a liberdade só florescia em Estados pequenos (55).

Por conta disso, quem, como Gonzaga, Luís Vieira ou Cláudio Manuel da Costa, quisesse se confrontar com o establishment redigindo subversivamente novas leis para a capitania, como eles de fato pretendiam fazer, não teria de indicar a necessidade de consolidação da vasta área colonial portuguesa sobum governo nacional e sim, como já ocorrera na América Inglesa, sublinhar seu compromisso com a decisão de vincular todo o sistema político a um processo de discussão e negociação específico ao legislativo. No contex to histórico da capitania das Minas, ao final do século XVIII, essa decisão só poderia ser traduzida por um projeto de recuperação do papel legislativo das câmaras municipais. Com efei- to, reduzir “as Minas a uma República”, afirmava, por exemplo, João de Resende Costa Filho, participante ativo dos serões sediciosos de São João del Rey, significava"fazerem vários parlamentos, um na dita Vila Rica, outro na de São João, e outros mais, ficando a vila de São João sendo a capital" (56).

Evidentemente, os letrados mineiros não tiveram a chance de acompanhar, no exemplo da América Inglesa, o longo caminho até Filadélfia, não assistiram aos legislativos assumindo despoticamente a administração da justiça ou apresentando as condições adequadas para viabilizar as ambições particulares dos indivíduos. Além disso, no caso específico das Minas, transferir a ênfase legislativa para as Câmaras Municipais significaria, mais cedo ou mais tarde, deparar-se com a mediocridade geral que caracterizou o comportamento político de seus membros.

Contudo, no mundo português, as Câmaras Municipais foram também o único instrumento de representação dos interesses locais e a única promessa de continuidade administrativa respaldada na autoridade conhecida pelas vilas coloniais. $\mathrm{Na}$ prática, essas Câmaras funcionavam como um instrumento decisivo de política da Coroa - em parte, porque simbolizavam estabilidade e continuidade administrativa e, em parte, também, porque atuavam como espaço de expressão de ressentimentos locais em relação ao fiscalismo da metrópole. Além disso, numa sociedade fluida e móvel como eram as Minas setecentistas, as Câmaras significavam o meio possível para homens novos, naturais do país, ocuparem cargos de governança da terra, ver reconhecida sua competência e politizada sua prestação de serviços ou sua aspiração de ascensão social (57).

Não era pouca coisa. Um outro indício muito característico da sensibilidade republicana que se formou na capitania das Minas, ao final do século XVIII, foi a intuição de que a soberania era de fato legislativa e, portanto, não podia ser compartilhada. Dessa descoberta, porém, derivava outra: a concepção, um tanto prosaica, é certo, de que 
havia algo muito pertinente na defesa do direito do indivíduo de desfrutar os próprios bens com imunidade contra a ação arbitrária do príncipe ou de seus representantes.

Não importava, nesse caso, se a república se ocultava sob a forma monárquica, como gostava de imaginar o cônego Luís Vieira; ou se, como queria padre Toledo, o critério de uma república bem ordenada devia basear-se na capacidade de seus dirigentes recrutarem seus cidadãos para defesa da pátria - ainda que para isso fosse necessário alforriar mulatos e negros nascidos na colônia. Os homens que participaram ou circularam em torno do grupo de letrados de Vila Rica, São João del Rey e São José del Rey tinham, todos eles, no geral, uma conduta política orientada pela utilidade, imaginavam a liberdade como "um bem que permite gozar todos os outros bens"(58) e se aproximaram da forma republicana a partir do reconhecimento compreensivo de que os interesses possuem valor agregativo. Nenhum desses homens pareceu disposto, em algum momento, a renunciar aos bens dessa vida em nome das antigas virtudes políticas ou militares ou da formação de uma consciência cívica.

Ao contrário. No geral, compartilhavam certa compreensão sobre a utilidade da virtude. Talvez não por acaso, tantos entre eles estiveram tão profundamente envolvidos com o contrabando. O padre Rolim, por exemplo, ocupou boa parte de sua vida metido em fraudes contra a Coroa: falsificou moeda, subornou autoridades - inclusive as eclesiásticas -, emprestou dinheiro a juros, conviveu com garimpeiros e faiscadores, desviou diamantes do Tejuco, onde nasceu, da rota oficial de Lisboa para a trilha clandestina que terminava em Amsterdã. Ele foi, sem dúvida, uma mistura bizarra e muito explosiva de contrabandista, agiota, aventureiro temerário e violento e, de quebra, sedutor incorrigível-um perso- nagem pouco disposto aos sacrifícios cegos ou à prática das virtudes antigas. Mas padre Rolim foi também, ao que tudo indica, um homem vocacionado pelas luzes do cálculo e, como boa parte de seus parceiros, um personagem capaz de romper o cordão de isolamento da privacidade individualista: na República que imaginava ajudara criar, o comércio seria livre, os diamantes, de propriedade de quem soubesse garimpá-los, os dízimos ficariam com os vigários, o ouro alçaria "seu legítimo valor".

É certo que a pretensão de uma forma republicana de governo para as Minas setecentistas fracassou - sobraram delitos de intenções, versos ambíguos, sermões atravessados, crimes de idéias, termos polissêmicos, excesso de loquacidade; ou, se quisermos enxergar de outro modo, sobraram a devassa, os interrogatórios, o suicídio, as prisões, o exílio, o enforcamento de Tiradentes. Contudo, a partir de então, o vocábulo "república" deixou de significar apenas e pejorativamente a ilustração retórica da decadência, da anarquia e da desordem como haviam afirmado, com tanta segurança, em 1720, o conde de Assumar, diante da sedição de Felipe dos Santos ou, em 1737, o governador Martinho Mendonça de Pina e Proença, às voltas com motins no sertão do São Francisco (59). Aos olhos das autoridades metropolitanas do século XVIII, o início da formação de uma imaginação republicana sobre a formação do bom governo, na capitania mais rica, mais populosa e estrategicamente melhor situada na América Portuguesa, certamente ainda era resultado da má qualidade dos povos das Minas. Contudo, traduzia uma novidade: como já havia previsto Maquiavel, na origem desse republicanismo que deixou alguns de seus traços na região das Minas, haveria ora em diante a possibilidade, sempre presente, de que os homens saibam e queiram manter suas mãos sobre a liberdade. Pensando bem, sobrou muita coisa.

\footnotetext{
58 Montesquieu, op. cit.

59 Discurso Histórico e Político so bre a Sublevação que nas $M$ nas Houve no Ano de 1720 op. cit." "Motins do Sertão Outras Ocorrências em Minas Gerais durante o Governo In terino de Martinho Mendonca de Pina e Proença conforme Correspondência deste com Governo da Metrópole", in Revista do Archivo Público Mineiro, 1, 1898.
} 